\title{
David Oliver: Who is to blame for older people's readmission?
}

\author{
David Oliver consultant in geriatrics and acute general medicine, Berkshire
}

In July Healthwatch England published Safely Home, a report describing the problems facing older people and their families when they leave hospital. ${ }^{1}$ Disturbing personal stories highlight poor coordination between services. Patients often feel stigmatised for problems they don't control—for instance, viewing themselves as "bed blockers," which is a dreadful term - and they are not always properly involved in very personal decisions.

Despite considerable efforts to plan hospital discharges well, about $15 \%$ of patients aged over 65 in England are readmitted within 28 days. ${ }^{2}$ Charities including Age $\mathrm{UK}^{3}$ and the Royal Voluntary Service ${ }^{4}$ have highlighted this distressing statistic and have publicised that support at home is often inadequate.

Simplistic media coverage may suggest a scandal, ${ }^{5}$ in which acute hospital staff are to blame- but the problem is far more complex. Many patients are readmitted not because the discharge was poorly planned or because they went home while still acutely unwell, but rather because of relapse of a long term condition or because of a new illness or injury. ${ }^{6}$ Intermediate care teams outside hospital have inadequate capacity to respond to crises or support discharge, and access to such care is too slow. ${ }^{7}$

Cuts to social care funding have left even people with "substantial" needs unsupported, as well as their carers. Older people with frailty or complexity and age related conditions receive generally less attention in primary care than those who are younger, and they often find poor coordination and continuity of care. ${ }^{8}$ Only a quarter of over $75 \mathrm{~s}$ admitted to hospital with conditions sensitive to management in primary care are referred by their GP; the rest present to emergency care. $^{9}$

Mentally competent older people who have expressed a clear wish to go home are often readmitted. But clinical staff who support their right to go home, however risky, are practising person centred care; to tell them "I told you so" misses this point.

The idea that hospital is "safe" while home is "unsafe" is false. Rather, prolonged hospital stays expose older people to considerable harms, often leading to a loss of function and independence - and a shorter length of stay is not correlated with readmission. ${ }^{10}$

Delayed transfers of care are becoming more common, and lengthy wrangling over NHS versus social care funding is a polar opposite to the idea of "putting patients first" that clinical commissioners and local authorities talk of in their "value statements." Furthermore, peer reviewed evidence on interventions to prevent readmissions is patchy. ${ }^{11}$

England has relatively few hospital beds and has lost them rapidly, and the unavailability of beds impairs the care of new acute patients. So, hospital staff are encouraged year round to discharge patients early to clear the beds; along with pressure from national performance targets, such as four hour waits, these are dominant daily priorities.

Well planned and well supported discharge matters greatly, of course, but the public needs to know the whole story about what acute hospital beds are for.

Competing interests: I have read and understood the BMJ policy on declaration of interests and have no relevant interests to declare.

Provenance and peer review: Commissioned; not externally peer reviewed.

Follow David on Twitter, @mancunianmedic

Healthwatch England. Safely home: what happens when people leave hospital and care settings? July 2015. www.healthwatch.co.uk/sites/healthwatch.co.uk/files/170715 healthwatch_special_inquiry_2015_1.pdf.

2 Nursing Times. Growing readmission rate sparks concerns about early discharge. 11 Feb 2013. www.nursingtimes.net/nursing-practice/specialisms/older-people/growingreadmission-rate-sparks-concern-around-early-discharge/5054823.article.

3 Lawrie M, Battye F; Age UK. Research report: older people's experience of hospital readmission. July 2012. www.ageuk.org.uk/Documents/EN-GB/For-professionals/Research/ Emergency_readmission_older_peoples_experiences.pdf?dtrk=true.

4 Royal Voluntary Service. Avoiding unhappy returns: radical reductions in readmissions, achieved with volunteers. Dec 2013. www.royalvoluntaryservice.org.uk/Uploads/ Documents/Get\%20involved/avoiding_unhappy_returns.pdf.

5 Feinmann J. The patients whose lives are put at risk by hospitals sending them home too soon. Daily Mail 2014 Nov 3. www.dailymail.co.uk/health/article-2819376/The-patientslives-risk-hospitals-sending-home-soon.html.

6 NHS Confederation, Foundation Trust Network. Briefing: the impact of non-payment for acute readmissions. Feb 2011. www.chks.co.uk/userfiles/files/The\%20impact\%20of\% 20non-payment\%20for\%20acute\%20readmissions\%20FINAL\%20FOR\%20WEB.pdf. NHS Benchmarking Network. National audit of intermediate care: summary report 2014. Nov 2014. www.nhsbenchmarking.nhs.uk/CubeCore/.uploads/NAIC/ NAICSummaryReport2014.pdf. 
8 National Institute for Health Research: Service Delivery and Organisation Programme. Understanding and improving transitions of older people: a user and carer centred approach. 2012. www.birmingham.ac.uk/Documents/news/SDOTransitions-Report.pdf.

9 Cowling TE, Soljak MA, Bell D, Majeed A. Emergency admissions via hospital accident and emergency departments in England: time trend, conceptual framework and policy implications. J R Soc Med 2014;107:432-8.

10 Macready N. Link between length of hospital stay and readmission rate. Medscape educational clinical briefs. 2012.
11 Conroy S, Dowsing T. What should we do about hospital readmissions? Age Ageing 2012;41:702-4.

Cite this as: BMJ 2015;351:h4244

(c) BMJ Publishing Group Ltd 2015 